\title{
高速双ロールキャスターで作製したアルミニウム合金板の エッジでのバリにサイドダムプレートが及ぼす影響*
}

\author{
山敷 拓也 ${ }^{* 1}$, 白川 祐樹 ${ }^{* 2}$, 羽賀 俊雄 ${ }^{* 3}$, 熊井 真次 ${ }^{* 4}$, 渡利 久規 ${ }^{* 5}$ \\ Effect of Side-Dam Plate on Burrs at Edges of Aluminum Alloy Strip \\ Fabricated by a High Speed Twin Roll Caster
}

\author{
Takuya YAMASHIKI ${ }^{*}$, Yuki SHIRAKAWA, Toshio HAGA, Shinji KUMAI and Hisaki WATARI \\ ${ }^{* 1}$ Graduate school of Osaka Institute of Technology, 5-16-1 Omiya Asahi-ku Osaka-city, 535-8585 Japan
}

\begin{abstract}
A high speed twin roll caster is able to cast an aluminum alloy strip directly from a molten metal at high casting speed. However burrs at edges of the cast strip occurred depending on used aluminum alloy. It is the special problem, which a conventional twin roll caster didn't have. Burrs damages side-dam plate used in a high speed twin roll caster. In addition, it may affect down-stream process. We predicted that burrs are rerating to flowability at semi-solidification. In this study, we adjusted side-dam plate lower end position at the casting, and investigated relationship between occurrence position of the burrs and amount of the Si. Additionally, it was added hole drilling for eliminating the burrs. We used AA6061, $\mathrm{AC} 4 \mathrm{CH}, \mathrm{ADC} 12, \mathrm{Al}-25 \% \mathrm{Si}$. As a result, occurrence positions of the burrs were different depending on amount of the Si. The Side-dam plate with the hole was possible to eliminate the burrs.
\end{abstract}

Key Words : Aluminum Alloy, Twin Roll Caster, Side-Dam Plate, Casting

\section{1. 緒言}

双ロールキャスティング法は溶融金属を 2 つ回転するロール間に注湯することにより，一工程で薄板の作製 が可能である. 双ロールキャスターは，おもに鉄鋼用とアルミニウム用がある(1)-(5). 先行研究よりアルミニウム 用双ロールキャスターの研究を行っており, 鋳造速度を従来の $2 \mathrm{~m} / \mathrm{min}$ 程度と比較して 30 倍以上高速化した縦型 高速双ロールキャスターが開発された ${ }^{(1)-(3)}$. 従来の双ロールキャスターはチップによる注湯のため, 作製される 板の幅はロール幅よりも狭い。一方, 縦型高速双ロールキャスターはサイドダム方式のため, ロール幅と等しい 薄板が得られる。また，縦型高速双ロールキャスターでアルミニウム薄板を鋳造する場合，ブレイクアウトを防 ぐためにも, 鉄鋼用の双ロールキャスターと比較して 10 倍程度, 板形成時にロール荷重が必要となる(4)(5). 上記 のような特徵から，合金によっては薄板のエッジにバリが著しい場合がある. 形成されるバリが合金によって異 なるため, バリの状態は，半凝固状態での流動性によって変化すると推測される．また，バリの影響でサイドダ ムプレートの一部が損傷する場合がある，損傷はロールキス部付近で顕著であることから，サイドダムプレート の位置を制御することで軽減できると推測した。

本研究では，サイドダムプレートの下端位置を調整し，バリの発生位置及び，バリの状態に Si 量が及ぼす影響 を調査した。 また，下工程への影響を考慮し，鋳造中に薄板のエッジからバリを除去し,バリの無い薄板の作製が 可能か調査した.

\footnotetext{
* 原稿受付 2012 年 12 月 5 日

${ }^{* 1}$ 学生員, 大阪工業大学大学院 工学研究科（干535-8585 大阪府大阪市旭区大宮 5-16-1）

*2 学生員, 大阪工業大学

*3 正員, 大阪工業大学

*4 東京工業大学

*5 群馬大学

E-mail:m1m11436@st.oit.ac.jp
} 


\section{2. サイドダムプレートの位置によるバリの状態の調査}

\section{$2 \cdot 1$ 実験装置及び，実験条件}

図 1 に本研究で使用する縦型高速双ロールキャスター(Vertical type High Speed Twin Roll Caster: HSTRC)の概略図を示 す. 装置は一対のロール, ノズルプレート, サイドダムプレート(Side-dam plate: SP), 荷重ばねから構成される.ロー ルは直径 $300 \mathrm{~mm}$ ，幅 $50 \mathrm{~mm}$ で，材質は銅である．本研究で用いる SP の概略図を図 2 に示す．板厚 $3.2 \mathrm{~mm}$ の軟鋼 板にガラス繊維断熱材を被覆している. 本研究では薄板エッジでのバリを分類した(図 3). (a)縦バリ，(b)横バリ， (c)バリなしとする. 鋳造時, 縦バリが発生した場合にはSPのロールキス部付近に削られた跡が残る(図 2(b)). SP 下端の位置を調整することで, 縦バリが横バリに変化する範囲, 寸なわち, バリの発生開始範囲の特定が可能で あると推測した．縦バリが横バリとなる SP 下端の位置を調査するため， ロールの中心間を結ぶ線上を基準位置 $\mathrm{L}_{\mathrm{C}}$ として, $\mathrm{SP}$ を方に $25 \mathrm{~mm}$ まで $5 \mathrm{~mm}$ 間隔で調節可能にしている（図 1).まず，バリの発生開始位置をある程 度推測するため, SP 下端を位置 $\mathrm{L}_{\mathrm{C}}$ に合わせて実験を行い, バリによってできた跡の SP 下端からの高さを計測し た。供試材は，Al-1\% Si (6061) , Al-7\% Si (AC4CH), Al-11\% Si (ADC12), Al-19\%Si（AC9B）である. 主となる鋳造条 件は, 注湯温度スーパーヒート $20^{\circ} \mathrm{C}$, ロール周速 $60 \mathrm{~m} / \mathrm{min}$, 凝固距離 $100 \mathrm{~mm}$ ，初期荷重 $376.8 \mathrm{~N} / \mathrm{mm}$ とした.

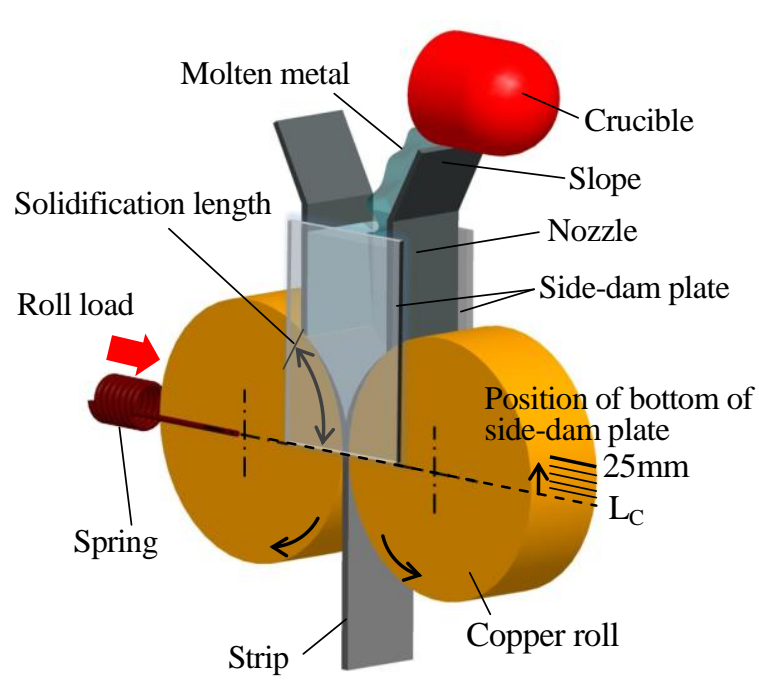

Fig.1 Vertical type High Speed Twin Roll Caster (a)

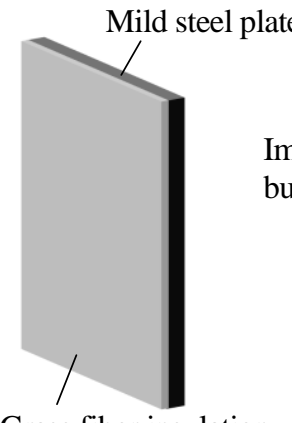

Grass fiber insulation

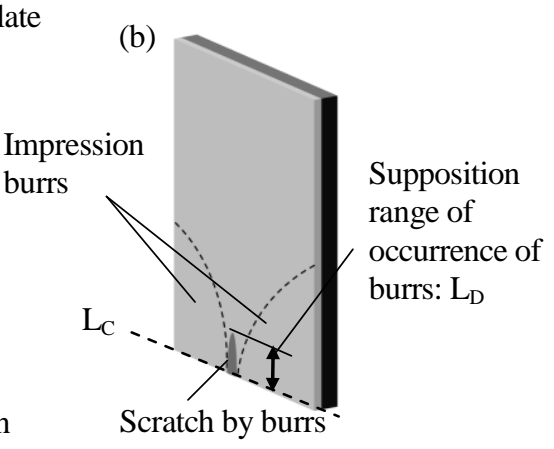

Scratch by burrs

Fig.2 Side-dam plate. (a)Before experiment, (b)After experiment

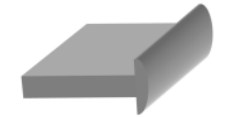

(a)Vertical burrs

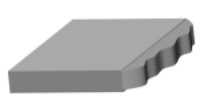

(b)Horizontal burrs

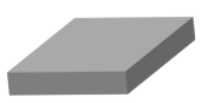

(c)Not burrs

Fig.3 Shape of burrs at edges of cast strips

\section{$2 \cdot 2$ サイドダムプレートの位置がバリの状態に及ぼす影響}

各合金で $\mathrm{SP}$ 下端を位置 $\mathrm{L}_{\mathrm{C}}$ で実験を行い，SP にみられる跡の $\mathrm{L}_{\mathrm{C}}$ からの高さについて計測した．結果は，6061 合金では $15 \mathrm{~mm}$ 程度であり，その他の合金は $25 \mathrm{~mm}$ 程度であった．計測で得た高さをバリが発生開始する推測位 置 $\mathrm{L}_{\mathrm{D}}$ とした．SP 下端の位置を位置 $\mathrm{L}_{\mathrm{D}}$ に合わせ，各合金で実験を行った。いずれの合金においても，SPの下端 から溶湯の漏れや, as-cast 板の板厚が薄く, 金属光沢が少ない状態であった. 推測位置 $\mathrm{L}_{\mathrm{D}}$ から, 縦バリが発生す るまで $5 \mathrm{~mm}$ 間隔で $\mathrm{SP}$ 下端の位置を下げて実験を行った． 6061 合金では基準位置 $\mathrm{L}_{\mathrm{C}}$ から $5 \mathrm{~mm}$ ，他の合金におい ては $15 \mathrm{~mm}$ から横バリとなり，SPに跡がなくかつ，金属光沢のある薄板の作製が可能であった. 上記よりも低い 位置では縦バリとなり, SP に跡が残ることから, 6061 合金では $\mathrm{L}_{\mathrm{C}}$ から $5 \mathrm{~mm}$, その他の合金では $10 \mathrm{~mm}$ から $15 \mathrm{~mm}$ の範囲でバリがはみ出し始めると考えられる. 図 4 に SP 下端位置 $\mathrm{L}_{\mathrm{C}}$ から $5 \mathrm{~mm}$ の条件で作製した 6061 合金薄板, L $\mathrm{L}_{\mathrm{C}}$ から $15 \mathrm{~mm}$ の高さで作製した AC4CH，ADC12，AC9B 薄板を示寸，合金によって，薄板の板幅方向にはみ出 したバリの状態に差がみられたため，はみ出したバリの長さを計測した． 6061 合金薄板では $1 \mathrm{~mm}$ から $2 \mathrm{~mm}$ ，そ の他の合金は $4 \mathrm{~mm}$ から $5 \mathrm{~mm}$ であった. Si 量が 7\%以上の Al-Si 系合金においては Si 量の増加に関係なく，はみ 出したバリの長さに差異がなかった。 バリの発生位置やはみ出した長さが $\mathrm{Si}$ 量によって変化することから, 半凝 固状態での流動性の差がバリの状態に影響していると考えられる．6061 合金は，液相線直下の準固相領域で半 

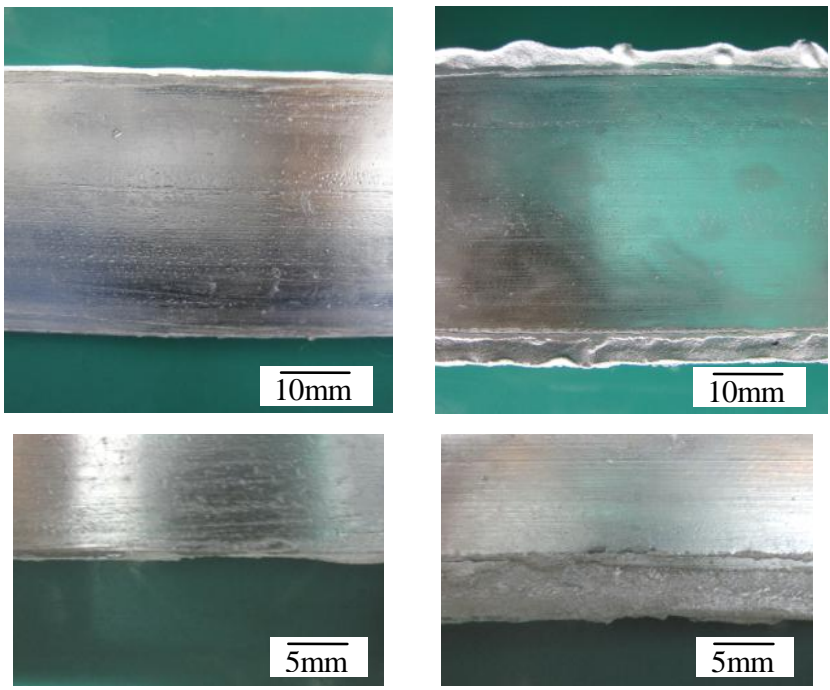

6061

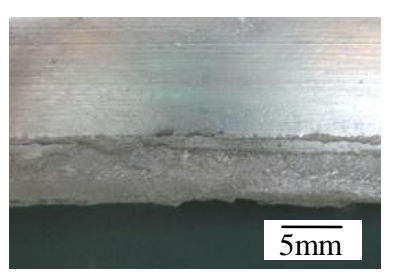

$\mathrm{AC} 4 \mathrm{CH}$
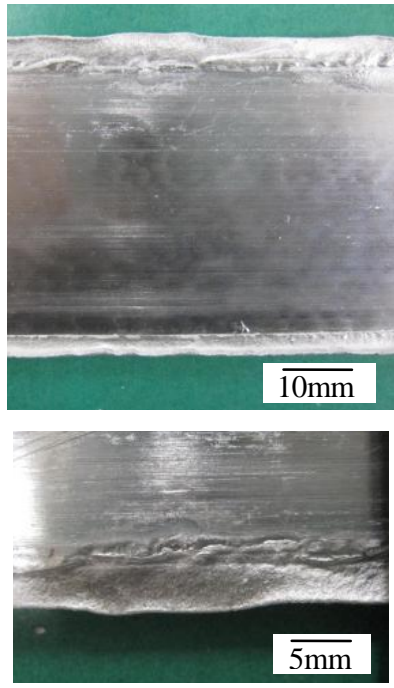

ADC12
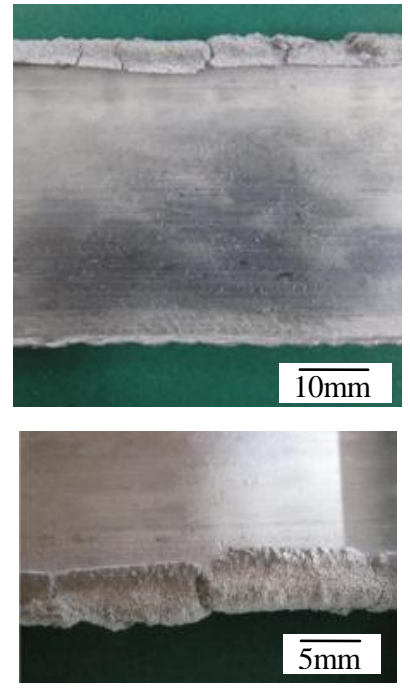

AC9B

Fig.4 As-cast strips with horizontal burrs. Upper: Surface of as-cast strips, Lower: Around burrs at edges of as-cast strips

凝固状態の流動性がなくなるため, ロール荷重が最も加わるロールキス部付近でバリがはみ出し, $\mathrm{Si}$ 量 $7 \%$ 以上 の合金では，半凝固状態の流動性が高いため，半凝固層が合流すると推測されるロールキス部から比較的高い位 置でバリがはみ出したと考えられる.Si 量 7\%以上の合金は, それぞれ固液相線範囲が異なるがバリの発生位置, 大きさに差異がなかった．これには半凝固状態での流動抵抗が関係していると考えられるため，今後，調査の必 要があるといえる. バリの状態は横バリとなったが，バリの厚みは 6061 合金で板厚とほぼ等しく，Si 量 7\%以上 の合金では板厚よりもバリは厚かった.

\section{3. 四角穴を付与したサイドダムプレートがバリの状態に及ぼす影響の調査}

\section{$3 \cdot 1$ 実験条件}

$\mathrm{SP}$ の位置を調整することでバリの状態は横バリとなり, SP の損傷を軽減できることは可能であった. しかし， バリの厚みが板厚よりも厚くなるため下工程に影響する. そこで，SP に四角穴を付与することにより，鋳造中， バリになると推測される未凝固物が四角穴から放出され, 四角穴の下端において未凝固物をせん断して除去でき るのではないかと考えた. 図 5 に四角穴付き SP, 図 6 に推測される鋳造中の様子の概略図を示寸. 四角穴の条件 は, 高さによる影響のみを調査するため幅は $10 \mathrm{~mm}$ とし, 四角穴の下端は $\mathrm{L}_{\mathrm{c}}$ で固定し, 上端を $\mathrm{L}_{\mathrm{E}}$ と定義して $\mathrm{L}_{\mathrm{c}}$ か ら $5 \mathrm{~mm}, 10 \mathrm{~mm}, 15 \mathrm{~mm}, 20 \mathrm{~mm}$ で実験した。断熱材は, 成型性の良いセラミックファイバー製紙状断熱材に変更 した．SPの材質は軟鋼板である．供試材は，上記試料の中でバリが最も発生する ADC12 とした．鋳造条件は， 注湯温度スーパーヒート $20^{\circ} \mathrm{C}$ ，ロール周速 $60 \mathrm{~m} / \mathrm{min}$ ，凝固距離 $100 \mathrm{~mm} ，$ 初期荷重 $376.8 \mathrm{~N} / \mathrm{mm}$ とした.

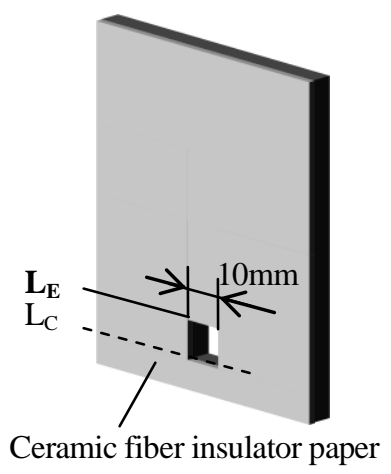

Fig.5 Side-dam plate with quadrilateral hole

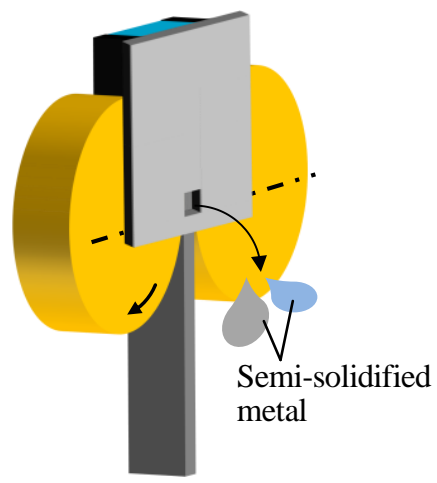

Fig.6 Schematic of the casting 


\section{$3 \cdot 2$ サイドダムプレートの四角穴がバリの状態に及ぼす影響}

四角穴上端 $\mathrm{L}_{\mathrm{E}}$ が $10 \mathrm{~mm}$ から $20 \mathrm{~mm}$ の条件では連続した薄板の作製が可能であった．薄板のエッジの状態は， $15 \mathrm{~mm} ， 20 \mathrm{~mm}$ でバリなし，10mm では稀に縦バリがみられた． $\mathrm{L}_{\mathrm{E}}$ が $5 \mathrm{~mm}$ では断続した薄板となり，縦バリが顕 著にみられた， $\mathrm{L}_{\mathrm{E}}$ が $5 \mathrm{~mm}$ ではバリの発生位置より低いため縦バリが形成される．10mm では，バリの発生位置 よりも低いため縦バリが形成されるが， $\mathrm{L}_{\mathrm{E}}$ が $5 \mathrm{~mm}$ の場合と比較して固相率が低かったため，四角穴を通過する 際にある程度は除去され，わずかに縦バリが残存したと考えられる. 図 7 に $\mathrm{L}_{\mathrm{E}}$ が $10 \mathrm{~mm}$ 及び， $15 \mathrm{~mm}$ の条件で作 製した薄板とそれらのエッジの状態を示す.エッジの状態から $\mathrm{L}_{\mathrm{E}}$ は $15 \mathrm{~mm}$ から $20 \mathrm{~mm}$ が適切であると判断した が，鋳造中の四角穴から放出される未凝固物の放出量に差異があったため，それらを採取し，薄板の重量に対す

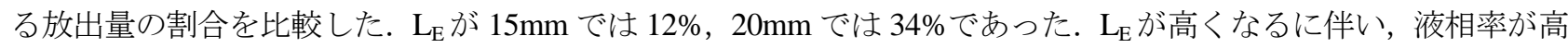
くなるため, 四角穴からの放出量が増え, 歩留りが低くなると考えられる， $\mathrm{L}_{\mathrm{E}}$ をバリの発生位置よりもわずか に高く設定することにより，歩留りが高く，良好な薄板の作製が可能であると考えられる.

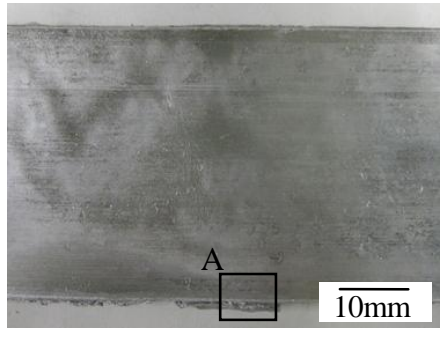

(a) $\mathrm{L}_{\mathrm{E}}: 10 \mathrm{~mm}$

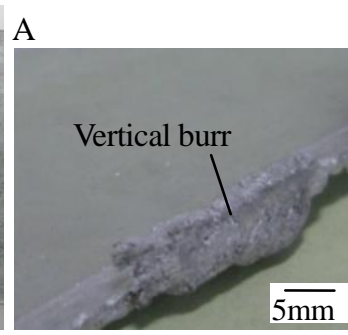

Fig.7 As-cast strips cast with the use of SP with quadrilateral hole
B
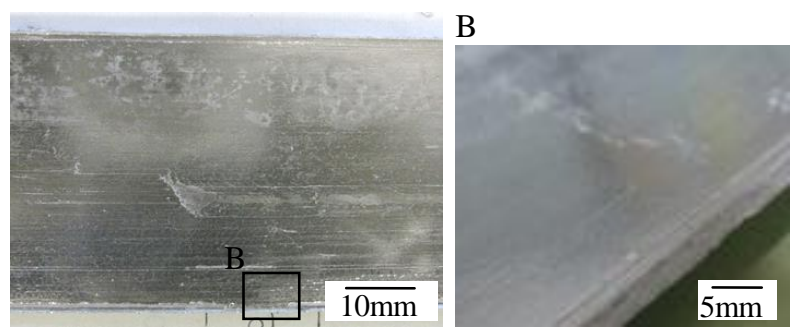

(b) $\mathrm{L}_{\mathrm{E}}: 15 \mathrm{~mm}$

\section{4. 結言}

本研究では, Al-Si 系合金を供試材とし, SP 下端の位置を調整することで薄板エッジのバリの発生位置及び, バリの状態に Si 量が及ぼす影響を調査した。また上記の実験結果より，SP に四角穴を付与し，鋳造中にバリの 除去が可能であるかの調査も行った。

バリの発生開始位置をある程度特定し，SP の下端位置をバリの発生位置よりもわずか上方に調整することで， 薄板エッジのバリの状態を縦バリから横バリに変化させることが可能であった． Si 量によって，バリの発生位置 やバリの大きさに差異がみられた．Si 量 $1 \%$ の合金は Si 量 7\%以上の合金と比較し，バリの発生位置は低く，バ リの大きさは小さかった. Si 量 7\%以上ではバリの発生位置及び，バリの大きさに差異がなかった.

バリの状態を横バリにすることは可能であったが下工程への影響を考慮し，バリを除去するため，SPに四角穴 を付与した。四角穴の下部でバリになると推測される未凝固物をせん断することは可能であった。四角穴の条件 によっては歩留まりが低くなるため，歩留まりを高くするための最適な四角穴の大きさ，または，穴の形状を調 査することが課題である.

\section{文献}

(1) 羽賀俊雄，“アルミニウム合金用双ロールキャスタ”，軽金属学会，Vol. 59, No.9（2009）， pp. 509-520.

(2) T. Haga, H. Sakaguchi, H. Watari, S. Kumai, "High speed twin roll caster for aluminum alloy thin strip", Journal of Achievements in Materials and Manufacturing Engineering, Vol.24(2007), pp. 365-371.

(3) T. Haga, M. Ikawa, H. Watari, S. Kumai, "High speed twin roll casting of Al-3Si-0.6Mg strip", Journal of Achievements in Materials and Manufacturing Engineering, Vol.17(2006), pp. 337-340.

(4) 溝口利明, 宮沢憲一, “18Cr-8Ni ステンレス鋼の双ロール鋳造における凝固組織の形成”, 鉄と鋼, Vol.81, No.1 (1995), pp.58-63.

（5）溝口利明，宮沢憲一，上島良之，“双ロール式ストリップ鋳造における鋳片表面性状とメニスカス形状の関係” 鉄 と鋼, Vol.81, No.6 (1995), pp.31-36. 